\title{
CRITICAL REVIEW OF BIM-BASED LCA METHOD TO BUILDINGS
}

\author{
Bernardette Soust-Verdaguer ${ }^{1}$, Carmen Llatas², Antonio García-Martínez ${ }^{3}$
}

${ }^{1}$ Department of Building Construction I, Escuela Técnica Superior de Arquitectura, University of Seville, Reina Mercedes 2, 41012 Seville, Spain; email: $\underline{\text { bsoust@ us.es }}$

${ }^{2}$ Department of Building Construction I, Escuela Técnica Superior de Arquitectura, University of Seville, Reina Mercedes 2, 41012 Seville, Spain; email: cllatas@ us.es

${ }^{3}$ Department of Building Construction I, Escuela Técnica Superior de Arquitectura, University of Seville, Reina Mercedes 2, 41012 Seville, Spain; email: agarcia6@us.es

\section{Corresponding author:}

Bernardette Soust-Verdaguer

Mailing Address: Department of Building Construction I, Escuela Técnica Superior de Arquitectura, University of Seville, Reina Mercedes 2, 41012 Seville, Spain.

Phone: (+34) 954556591

Email: bsoust@us.es 


\section{CRITICAL REVIEW OF BIM-BASED LCA METHOD TO BUILDINGS}

\section{Abstract}

Current environmental problems arising from the building sector require tools to help reduce resource consumption and environmental impact. Life cycle assessment (LCA) is a widely used tool to quantify the environmental impacts of the building sector. The literature recognizes the need to simplify the method application, especially to reduce and optimize data acquisition. Building Information Modeling (BIM) is defined as a virtual 3D building model which integrates with a database of their building elements. Several studies recognize that the integration of BIM and LCA can simplify data acquisition of the building as well as provide both tools with feedback. This paper reviews recent studies centered on BIM-based LCA, and also carries out a methodological analysis of their integration, focusing on the way that BIM can contribute to simplifying data input, and optimize output data and results during the LCA application in buildings. The results show the viability to develop methods based on BIM models for organizing building information used to estimate environmental and energy consumption impacts based on LCA, including: templates and plug-ins for BIM software, and the integration of automated processes combining different data and software. Reviewed papers are simplified LCA applications, mostly focused on CO2 emission calculation during the early stages of design. Finally, methodological challenges and recommendations for BIM and LCA tools are proposed.

Key words: Building Information Modeling (BIM), Life Cycle Assessment (LCA), Life Cycle Energy Analysis (LCEA), Buildings.

Abbreviations: AEC, Architecture Engineering Construction; BIM, Building Information Modeling; EE, Embodied Emissions; GDL, Geometric Description Language; IFC, Industry Foundation Classes; LCA, Life Cycle Assessment; LCI, Life Cycle Inventory; LCIA, Life Cycle Impact Assessment; LCC, Life Cycle Cost; LCCA, Life Cycle Cost Assessment; LOD Level of Development; OE, Operational Emissions. 


\section{INTRODUCTION}

The building sector is recognized as the most important natural resources consumer. Globally, it consumes $32 \%$ of resources including $12 \%$ water and $40 \%$ energy [1]. Moreover the building sector is the main waste producer -generating one third of European waste [2] and it is responsible for $22 \%$ of European hazardous waste production [3].

Sustainable development is widely recognized as one of the most important strategies in reducing the environmental impact of the building sector [4-7]. There are several tools and methods to help the implementation of sustainable development into the built environment [8-11]. Life Cycle Assessment (LCA) is considered as a complete method to assess the sustainability of a building over its life cycle; and has growing importance in the scientific community [12]. Several studies underline the importance of improving and simplifying LCA application to buildings [13-16]. Thus, it is recognized that the integration of BIM (Building Information Modeling) - LCA can reduce and optimize LCA application [13].

BIM software can hold graphic information as well as material properties about building elements that the building comprises [17]. It is also identified as a helpful tool that can considerably reduce the time and effort required to manage graphics and data about the building [18,19]. Young et al. [20] recognize its potential towards sustainable design. Kwok et al. [21] developed a review of existing papers which focused on BIM to monitor environmental sustainability and manage buildings throughout their complete life cycle.

The development of methods that integrate BIM and LCA is growing. Alvarez and Díaz [22] underline the importance of including LCA in BIM environment, especially in early stages of design. Kreiner et al. [23] developed a systemic approach based on the LCA method. It concludes that improvements of sustainability performance of buildings can be carried out by integrating BIM with the developed approach. However, the development of the 'cradle-to-grave' comprehensive BIM-based environmental sustainability simulation tool is still scarce [21].

An example of BIM-LCA integration is Tally [24], a plug-in for Autodesk Revit that quantifies environmental impacts of building materials based on the LCA method, as well as allowing a comparative analysis of design options. At the moment the application is geographically adapted to the US region [24]. 
The lack of reviews that analyzes the integration of BIM and LCA is identified as a gap in the literature. For this reason, this paper aims to review recent case studies that integrate BIM and LCA. The paper discusses methodological aspects of the use of BIM for Life Cycle Assessment of buildings, focuses on how BIM can simplify and reduce data acquisition during LCA application; and looks at how LCA can enhance BIM performance for building design. Finally, methodological aspects and recommendations are developed.

\section{BIM TOOLS FOR SUSTAINABLE DESIGN}

Currently, the use of BIM in AEC (Architecture Engineering Construction) is growing globally. According to Directive European 2014/24/EU [25] the use of BIM for public building will be compulsory in the EU from October 2018. Countries such as the UK have already adopted BIM for public procurements from $2016[26]$

\subsection{BIM and sustainable design}

The use of BIM tools involves the definition of a virtual model which includes graphic information and data about materials and components of the building. The level of detail or development is a concept used to describe information richness of this BIM model, and it is defined by the amount of information about the building [27]. According to the American Institute of Architecture (AIA), the level of development (LOD) "describes the minimum dimensional, spatial, quantitative, qualitative, and other data included in a Model Element". The AIA recognizes five levels: LOD 100, LOD 200, LOD 300, LOD 400 and 500. This classification identifies the specific minimum content requirements [28] and it is defined depending on the graphic and data information included in the model.

Several papers emphasize the potential of BIM to include environmental information to assess and help with decision-making [21-23,29]. Its potential for sustainable design is that BIM can improve a project's information flow, achieving better performance and quality [30]. That fact allows users to obtain information quickly on specific materials and wall structures and it also provides a visualization tool for sustainable buildings [31].

Hardin \& McCool [32] recognized three areas for sustainable design related to BIM: material selection and use, site selection and management, and system analysis. Other studies recognized the potential of BIM towards the reduction of environmental impacts in the building sector [1,33-35]. As well as Hardin and 
McCool [32], Kriegel and Nies [36] underlined the utility of BIM for sustainable design, focusing, among others, on: energy modeling (to reduce energy demand and analyze the integration of renewable energy options), sustainable materials (to reduce embodied energy) and site and logistics management (to reduce waste and carbon footprints).

Thus, several papers demonstrated the use of BIM for sustainable design. BIM for Daylight simulation is developed in Kota et al. [17]. The study showed the use of BIM for daylight analysis and also developed a validation of a prototype integrating Revit with Radiance and DAYSIM (daylighting simulation tools). Moreover, a framework to optimize the energy performance of buildings was presented in Rahmani Asl et al. [37]. The paper showed the use of the BPOpt (Building performance optimization) framework, a visual programing and parametric BIM-based design space exploration, to find the optimal solution. Also, Mah et al. [38] developed a methodology to quantify the $\mathrm{CO} 2$ footprint of a house construction process in Canada, rooted for the application of BIM.

The use of BIM is also identified for waste reduction and deconstruction for sustainable design. Rajendra \& Pathrose [39] confirmed the growing interest and benefits of the use of BIM for this purpose, through the revision of different waste reduction strategies applied across BIM. Liu et al [40] developed a decisionmaking framework to reduce waste production integrated to BIM. Akbarnezhad et al. [34] carried out other types of decision-making frameworks, integrating different deconstruction scenarios for the analysis. The study integrated BIM with recycling and reusing strategies of building materials. The developed methodology allowed the selection of the best deconstruction strategy for the building according to economic and environmental criteria. Ahankoob et al. [41] explored the potential of BIM for including strategies for waste reduction. Cheug et al. [42] developed a tool for the management of construction and demolition waste, and also demonstrated its utility as a BIM tool.

\subsection{BIM-LCA integration}

LCA is recognized as a powerful tool to assess environmental impacts [43]. According to ISO 14040 [44] LCA method consists of four phases: goal and scope, life cycle inventory (LCI), life cycle impact assessment (LCIA) and interpretation. The ISO 14040 [44] standard also establishes that the LCA method represents the life cycle of a product as a system. This system is composed of unit processes which helps the identification of input and output flows [44]. 
The LCA application within the building sector, as a strategy to reduce environmental impacts and the energy consumption of the building sector, has been underlined in several review papers [11,13,43,45-47]. However, prejudices about the complexity [48-52] and time-consuming nature of the LCA application in buildings were detected $[49,52,53]$. The EeBGuide Handbook recognized that the use of the LCA method in the building sector cannot be developed with the same level of detail as in other sectors [54]. Therefore, three types of LCA studies were established: Screening LCA, Simplified LCA and Complete LCA. The criteria to define each level were based, among others, on: the goal and scope of the assessment, the experience of the practitioner, the data availability and the state of development of the building [54]. Moreover, the Enslic project [55] also classified the level in performing the LCA and the experience of the practitioner as follows: basic calculation, developed in Excel, considers simple input and output data taking into account few environmental impact indicators, limited or no experience is needed to use this type of tool; medium calculation, using building specific tools such as Ecosoft, Equer, Athena (Impact Estimator and EcoCalculator), which require a medium level of experience; and advance calculation in which a high level of experience in LCA software as Simapro and Gabi is required.

The literature recognizes the advantages of BIM-LCA integration [13,23,33,49,56-59]. Kreiner et al. [23], who developed a methodology for building environmental assessment based on LCA, acknowledged the integration of LCA in BIM as a way of improving sustainability performance of buildings. Soust-Verdaguer et al. [13] demonstrated the growing use of BIM in LCA of single-family houses.

In spite of the fact that the integration of BIM-LCA can reduce time and improve the application environmental performance of buildings from the early stages of design, certain methodological challenges are detected in theoretical terms. Several papers which analyzed the integration from a methodological point of view highlighted the software integration as one of the most important challenges $[30,60]$. Håkkinen \& Kiviniemi [60], for instance, underlined the abundance of data requirements for BIM-LCA integration. They assumed that a separate software solution connected to BIM would be easy to implement and user-friendly. The proposed solution for software integration was based on linking separate software via file exchange, adding functionability to existing BIM software and using parametric formats such as Geometric Descripton Language (GDL) [60]. Furthermore, Rahmani Asl et al. [37], demonstrated the use of a BIM-based tool (a parametric energy and daylighting simulation tool). They highlighted as a significant challenge the interoperability work among the various purpose-built software applications, including BIM (Revit), energy simulation (Green Building Studio), daylighting simulation (Autodesk Ren- dering 
Service), and optimization (the new Optimo implementing NSGA-II). Seo et al. [61] proposed a method which uses a 3D CAD building model to visualize the environmental impacts resulting from the combination of design and choice of materials used in construction.

The most effective way of BIM-LCA integration is another issue identified in the reference literature $[22,62]$. Several studies underline that BIM-LCA integration is useful provided that the amount of data, the assessment process and the results are user-friendly and facilitate the LCA application [62]. Theoretically, data input and output (results) define the relevance of the integration and focus on the simplification and feedback from BIM and LCA tools. Given the absence of review papers that analyze case studies focusing on this subject, the present paper analyzes this integration in order to define the improvements and challenges for reducing building environmental impacts and energy consumption.

\section{MATERIALS AND METHODS}

In response to the observed gaps in the literature, the methodological aspects and challenges are analyzed, and also the contribution of BIM to improve input and output data during the LCA application, towards reducing building environmental impacts and energy consumption is discussed.

For the analysis of the case studies, an information flow structure based on the essential steps of LCA Design defined by Seo et al [61]: input, analysis and solution, is proposed. The input step creates the building 3D model definition, estimates all materials and gross building environmental burdens, and determines all specified manufactured components in a database of reasoning rules linked to LCI and LCC [61]. The analysis step is based on the calculation of a series of environmental indicators based on LCA, and the analysis of alternative designs [61]. The solution step includes the comparison of the environmental impacts of alternative designs and aims to facilitate the development of a combined building and materials [61]. The information flow structure included in Table 1, analyzes the following aspects in the present papers: data input (Table 2), data analysis (Table 3), outputs and communication of results (Table 4). 
Table 1.

Description of criteria to analyze case studies.

\begin{tabular}{cll}
\hline Data Input & Data analysis & Outputs and communication of results \\
\hline BIM model & & Environmental impact indicator \\
$-\quad$ Level of development & BIM software & Sensitivity analysis \\
LCA method & Energy Consumption & \\
$-\quad$ Goal and scope & Calculation & $\begin{array}{l}\text { Embodied } \mathrm{CO} 2 \text { emissions ratio } \\
\left(\mathrm{Kg} / \mathrm{m}^{2} / \mathrm{year}\right)\end{array}$ \\
$-\quad$ LCA stages definition & (Software or method) & Operational CO2 emissions ratio \\
Life Cycle Inventory & LCA tool & $\left(\mathrm{Kg} / \mathrm{m}^{2} / \mathrm{year}\right)$ \\
\hline
\end{tabular}

\subsection{Selection of case studies}

A comprehensive literature search was based on recent publications that integrate BIM and LCA to calculate environmental impacts, energy consumption and embodied impacts of a building. The selection of papers was based on the following literature sources: Web of Science, American Society of Civil Engineers, Emerald, Mendeley, Sage Journals, Science Direct, Scopus, Springer Link, Taylor and Francis, Wiley Online Library, and Google Scholar, limited to journal publications in the last five years, the period of time since the publication of the European standard (EN 15978) about the LCA application to buildings.

\subsubsection{Criteria to analyze data input}

The level of detail and data input during the BIM modeling and the LCA application has an important role in BIM-LCA integration. Input data refers to the information that is defined about the building model and concerns the physical characteristics of the building model covering processes and phases of the LCA method. Data input corresponds to the process of storage and entering the input data. A set of criteria has been defined to analyze data input and included in Table 2. The table analyzes information about BIM modeling, including the level of development; and LCA method input data, including goals and scopes, LCA stages definition and LCI.

\subsubsection{Criteria to analyze data analysis}

The data analysis involves the process of transference between BIM software, data from environmental databases, data from energy consumption simulation and the LCA software tool. Therefore, the software integration is the most important aspect since it allows the data exchange and it can also simplify input and 
output data. Table 3 contains a summary of the main aspects of data exchange detected in the case studies, including: BIM software, software use for energy consumption simulation and the LCA tool.

\subsubsection{Criteria to analyze output data and communication of results}

Output data and communication of results are the final steps towards the BIM-LCA integration and justify among others, the integration of the two tools. Analyzed aspects are: the reduction and simplification of the output data, the potentials of the data processing and the comparability of the results. Table 4 summarizes the main aspects of the output data of the selected papers, containing: calculated environmental indicators, most common usage of results (sensitive analysis), estimated ratio (per year) of the most calculated environmental indicator (CO2 emissions) during the most calculated LCA phases (production and consumption).

\section{RESULTS}

\subsection{Data input}

It is assumed that data input is the most time consuming phase during the LCA application to buildings. Ajayi et al. [33] recognized the complexity and time-consuming nature of compiling input data during the LCI, and they also pointed out that it limits LCA application in the building sector. Thus, Loh et al. [63] pointed out the need to improve the inefficiency of data input into LCA software and the problem of data interoperability. On the other hand, it is recognized that the use of BIM for the LCA application can considerably reduce data input [13]. Data involved in the LCA process comprises the information about the building (graphics) and the environmental information about the building. Therefore, the results of the input data are organized as follows: BIM model input comprising the physical model and the LCA input data composing the environmental characteristics of the building materials and elements, the life cycle scenarios and the assumed phases. This information defines the amount of data that will be provided to develop the LCA application.

\subsubsection{BIM model input}

The development of the physical model provides manageable elements by designers from the early stages of design that are defined in the BIM modeling. In that sense, the level of development of the physical model (BIM modeling) defines the level of detail that will be developed through the LCA application. 
Reviewed papers assume the model definition as a crucial stage during the LCA application. Ajayi et al. [33] were based on a LOD 200 model to obtain the approximate quantities, size, shape, location, and orientation that were required for both energy analysis and quantitative estimates. Basbagill et al. [49] did not identify a standard to define the level of detail, although a list of BIM inputs in terms of constraints, variables, and assumptions was developed. Maximum and minimum values of variable inputs were included and the automated design-feedback process was supported by the use of several formulae for quantifying materials. Lee et al. [59] specified that the developed study required a LOD 300. Peng [64], Jalaei \& Jrade [57], Jrade \& Jalaei [58], Iddon \& Firth. [65], Georges et al. [66] and Houlihan et al.[67], Shin \& Cho [68] did not specify the level of development of the model, although Georges et al. [66] and Houlihan et al.[67] organized the data about building elements and components according to the Norwegian Standard NS 3451[69].

\subsubsection{LCA method input}

Reviewed papers have assumed the complete building as the functional unit to develop the LCA, except Georges et al. [51] and Houlihan et al. [52] that considered $1 \mathrm{~m}^{2}$ of heated area. Concerning the building characteristics, most cases were based on building projects $[33,57-59,65,66]$ while just one case centered on an existing building [64]. Moreover, the building typologies assessed were office $[57,66,68,70]$, residential [49,59,65-67], school [33] and university [64].

The lifespan was described in few cases. Only four cases have specified the lifespan considered to develop the LCA. The omission corresponds in several cases, to the exclusion of the end of life phase to develop the environmental assessment.

The LCA stages are also related to the goal and scope of the system and its definitions involve system limit definition. Although the EN 15978 standard establishes four stages for LCA application in buildings (product stage, construction stage, use stage, end of life stage), several cases $[49,57,58,65-68]$ focused on product and use stages (partially), excluding construction and end of life. For instance, Basbagill et al. [49] focused on product and operational energy consumption use; therefore, construction stages, use stage (partially) and end of life stages are not considered. 
Moreover, Lee et al. [59] developed an embodied environmental impact factor calculation for all life cycle stages (Product, Construction, Use, End of life) of the six major building materials. The processes included the transportation information, and the fuel efficiency of the major building materials. Moreover, Ajayi et al. [33] and Peng et al. [64] developed a comparative analysis of environmental impacts including all life cycle stages. However, recycling and reuse potential stages were not included in the case studies.

The data sources to develop the Life Cycle inventory (LCI) involve the collection and quantification of input and output data for building materials, building operations and processes over the building life cycle [4]. LCI of case studies considered mostly building materials, while building operations and processes (excluding energy consumption), were scarcely considered.

The use of generic databases has been verified in Georges et al. [66] and Houlihan et al. [67]. However, Shafiq et al. [70] developed the LCI based on the applications of an extra regional database. The study used a UK database to assess a Malaysian case, due to the inexistence of local or regional databases for the case study [70].

In contrast, the use of regional databases has been identified in Ajayi et al. [33], Jrade \& Jalaei [58], Jalaei \& Jrade [57], Iddon \& Firth [65], Lee et al. [59] and Shin \& Cho [68]. Most Canada and US cases [33,57,58] used Athena Impact Calculator, applicable for all North American building types [71]. 
Table 2.

LCA input summary of reviewed papers.

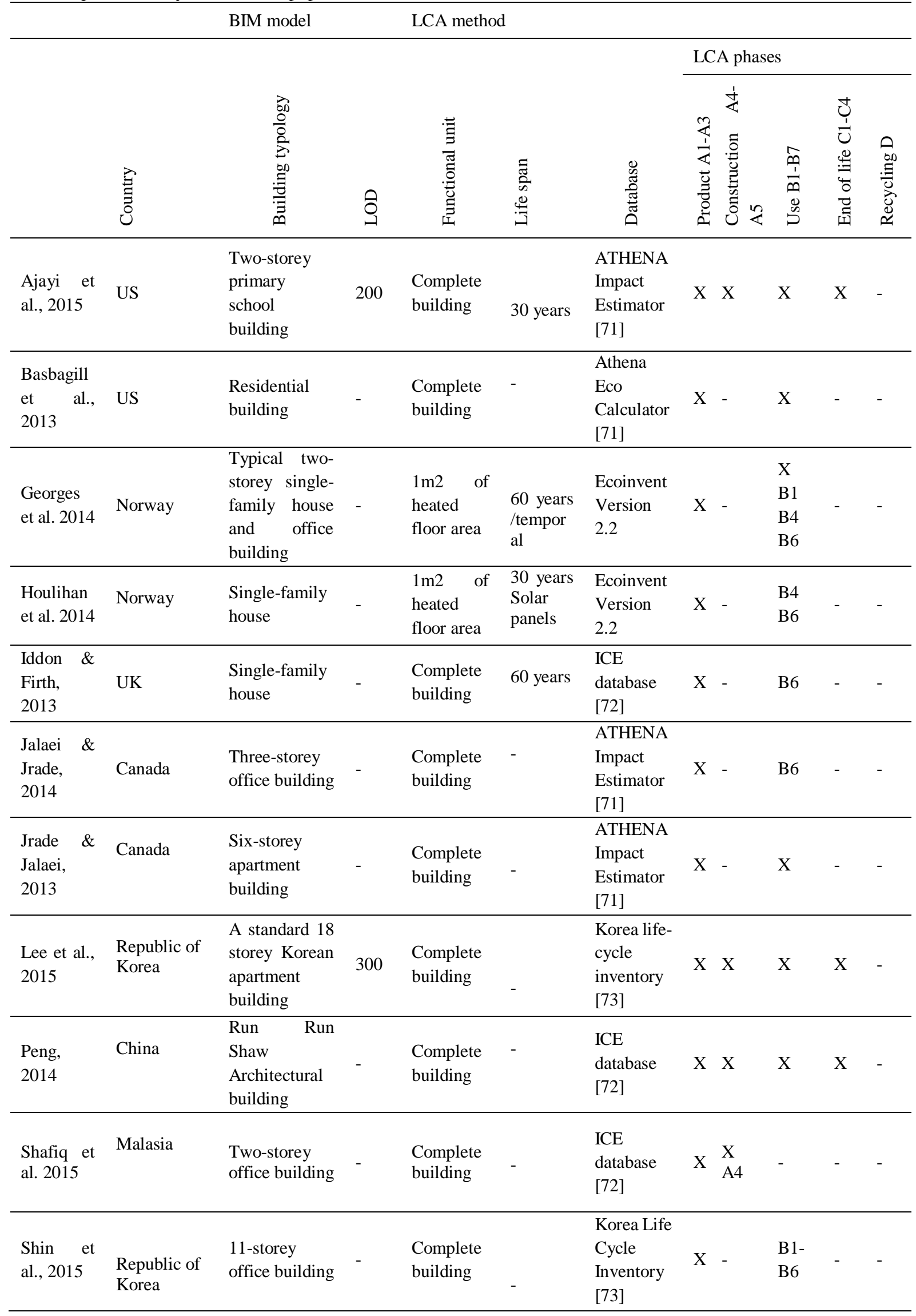




\subsection{Data analysis and software integration}

According to Seo et al. [61] data analysis involves the calculation of required performance indicators. This process depends on the software integration and the data exchange between BIM software and LCA application.

Several methodological approaches to the software integration and subsequently the validation of the proposed methodology have been detected in case studies. Ajayi et al. [33] carried out a method combining Revit, GBS, Microsoft Excel spreadsheets and the ATHENA Impact Estimator. Basbagill et al. [49] developed a method combining BIM software with LCA, energy simulation, and sensitivity analysis software, focused on early stages of design. The Georges et al. [66] method consists of exporting material and component quantities from REVIT model to Excel. Given the quantities, the EE is obtained based on Ecoinvent database version 2.2. Jalaei \& Jarde [57] developed a plug-in for the BIM tool to measure the environmental impacts and embodied energy of building components, using Autodesk Revit, Autodesk Ecotect, Integrated Environmental Solutions (IES-VE), Microsoft Excel, and Athena Impact Estimator. Jarde \& Jalaei [58] developed a model that includes a database about sustainable materials, linked to an LCA module and a certification and cost module. Shafiq et al.[70] developed an LCA application limited to carbon footprints; the embodied carbon emissions from material manufacturing and transportation activity were calculated using Equation. Shin \& Cho [68] demonstrated the usability of the BIM to develop the LCA and LCCA, the framework developed was applied to analyze three external skin systems for a building.

Peng [64] developed a study of the life cycle of carbon emissions of a building using Autodesk Revit and Autodesk Ecotect to simulate the heating and cooling loads during the operational stage. The study obtained the total amount of $\mathrm{CO} 2$ emissions as the sum of the $\mathrm{CO} 2$ emissions generated during the construction, operational, and demolition stages [64].

Lee et al. [59] developed a green template that provides databases for the embodied environmental impact evaluation of a building using Autodesk Revit. The study provides a template that contains instructions on how to construct a library and environmental information databases [59]. The template can be used as a library of building elements, intended to check the embodied environmental impacts [59]. 
Iddon \& Firth [65] used two separate and identical models to calculate simultaneously operational and embodied carbon. The operational carbon is calculated in a SAP based spreadsheet. The separated calculations derive their input data from the central database containing all material technical data [65].

In spite of the geographical heterogeneity of case studies, Ajayi et al. [33], Georges et al. [66], Houlihan et al. [67], Jalaei \& Jrade [57], Jrade \& Jalaei [58], Lee et al. [59], Peng [64], Shariq et al. [70], used Autodesk Revit to develop the BIM model. The use of other BIM softwares was detected in Basbagill et al. [49] and Shin \& Cho [68]. Basbagill et al. [49], for instance, selected DProfiler as the BIM modeler software, due to the detailed BIM outputs with fewer inputs than Autodesk Revit. Moreover, the DProfiler file can also be automatically exported to eQUEST, an energy simulation program. Meanwhile, Shin \& Cho [68], selected ArchiCAD 15 as the BIM software modeler and the EcoDesigner (an add-on function) to calculate the energy consumption.

Data exchange between BIM and LCA is another important issue in the integration of both tools. One of the most important uses of BIM during the LCA application is to obtain the bill of material quantities. According to Table 3 most of the case studies started from the BIM automatic estimation of each material quantities and then exported the list to an Excel sheet where data are manually enriched and organized before developing the LCA application. Basbagill [49] for example, started from the BIM model and used formulae to calculate minimum and maximum possible quantities for each building component material. Georges et al. [66] and Houlihan et al. [67] exported length, area and volume of materials from Revit to Excel and then used the quantities to calculate the embodied emissions. Ajayi et al. [33] generated a BIM model and then used an Excel spreadsheet to determine the materials that contributed to each of the components. Iddon et al. [65] developed an Excel spreadsheet adapted for use with a BIM database containing technical data for the building materials, so as to generate operational and embodied carbon dioxide emissions. Peng et al. [64] also used the BIM model to obtain the bill of materials, and the CO2 emissions were calculated using a formula based on "The National Greenhouse Gas Inventories Programme" [74]. Shafiq et al. [70] also extracted the quantities of the structural materials from the virtually constructed 3D models in Microsoft Excel file format.

Shin \& Cho [68] extracted automatically the quantity information for each material from the BIM software, including: weight, equivalent volume, area and length values. The framework automatically connects the LCA with LCCA methods and the data on each sheet can be entered manually after it has been extracted 
automatically using BIM software [68]. Jrade \& Jalaei [58] developed a model that is not fully automated, so users have to link the BIM model's information with LCA tools to develop LCA, and cost estimate calculations.

On the other hand, Jalaei \& Jrade [57] elaborated an "automated method" to link green materials databases, BIM tools, energy and lighting analysis, LCA and LEED and cost assessment. However, it concludes that some information needs to be entered manually by the user after the transferring process [57]. Lee et al. [59] developed a green template that provides databases for the embodied environmental impact evaluation, using only Revit as the BIM authoring software.

As well as the data exchange, several cases underlined certain geometric characteristics, simplifications or adaptations of the model design towards BIM-LCA integration. Basbagill [49] for example, underlined that BIM geometries have been simplified and limited to fairly simple orthogonal building shapes such as the H-shaped. Jrade \& Jalaei [58] designed in a modular format, incorporating the foregoing modules, which means that the information about different parts of each green family such as windows was saved in the external database. In Houlihan et al. [67], the considered BIM model simplified part of the wall components, and the load bearing wood stud members in the outer and inner wall components were calculated independently to the BIM software. 
Table 3.

Software integration and data exchange summary.

\begin{tabular}{|c|c|c|c|c|}
\hline Reference & BIM software & $\begin{array}{l}\text { Energy } \\
\text { consumption } \\
\text { calculation }\end{array}$ & $\begin{array}{l}\text { Data } \\
\text { exchange } \\
\text { procedure }\end{array}$ & LCA tool \\
\hline Ajayi et al., 2015 & $\begin{array}{l}\text { Autodesk Revit } \\
\text { Architecture }\end{array}$ & $\begin{array}{l}\text { Green Building } \\
\text { Studio (GBS) }\end{array}$ & $\begin{array}{l}\text { From BIM to } \\
\text { Excel sheet }\end{array}$ & $\begin{array}{l}\text { ATHENA Impact } \\
\text { Estimator }\end{array}$ \\
\hline $\begin{array}{l}\text { Basbagill et al., } \\
2013\end{array}$ & DProfiler & eQUEST & $\begin{array}{l}\text { From BIM to } \\
\text { Excel sheet }\end{array}$ & $\begin{array}{l}\text { SimaPro, } \\
\text { ATHENA } \\
\text { EcoCalculator }\end{array}$ \\
\hline $\begin{array}{l}\text { Georges et al. } \\
2014\end{array}$ & $\begin{array}{l}\text { Autodesk Revit } \\
\text { Architecture }\end{array}$ & SIMIEN & $\begin{array}{l}\text { From BIM to } \\
\text { Excel sheet }\end{array}$ & $\begin{array}{l}\text { SimaPro version } \\
7.3\end{array}$ \\
\hline $\begin{array}{l}\text { Houlihan et al. } \\
2014\end{array}$ & $\begin{array}{l}\text { Autodesk Revit } \\
\text { Architecture }\end{array}$ & SIMIEN & $\begin{array}{l}\text { From BIM to } \\
\text { Excel sheet }\end{array}$ & $\begin{array}{l}\text { SimaPro version } \\
7.3\end{array}$ \\
\hline $\begin{array}{l}\text { Iddon \& Firth, } \\
2013\end{array}$ & - & $\begin{array}{l}\text { Standard Assessment } \\
\text { Procedure for energy } \\
\text { rating of dwellings } \\
2009 \text { version } 9.9[75]\end{array}$ & $\begin{array}{l}\text { From BIM to } \\
\text { Excel sheet }\end{array}$ & - \\
\hline $\begin{array}{l}\text { Jalaei \& Jrade, } \\
2014\end{array}$ & $\begin{array}{l}\text { Autodesk Revit } \\
\text { Architecture }\end{array}$ & $\begin{array}{l}\text { Autodesk Ecotect, } \\
\text { Integrated } \\
\text { Environmental } \\
\text { Solutions }\end{array}$ & $\begin{array}{l}\text { From BIM } \\
\text { trough ODBC } \\
\text { exporting } \\
\text { format }\end{array}$ & $\begin{array}{l}\text { Athena Impact } \\
\text { Estimator }\end{array}$ \\
\hline $\begin{array}{l}\text { Jrade \& Jalaei, } \\
2013\end{array}$ & $\begin{array}{l}\text { Autodesk Revit } \\
\text { Architecture }\end{array}$ & Autodesk Ecotect & $\begin{array}{l}\text { From BIM to } \\
\text { external } \\
\text { database }\end{array}$ & $\begin{array}{l}\text { ATHENA Impact } \\
\text { Estimator }\end{array}$ \\
\hline Lee et al., 2015 & $\begin{array}{l}\text { Autodesk Revit } \\
\text { Architecture }\end{array}$ & - & $\begin{array}{l}\text { Database link } \\
\text { to BIM }\end{array}$ & - \\
\hline Peng, 2014 & $\begin{array}{l}\text { Autodesk Revit } \\
\text { Architecture }\end{array}$ & Ecotect & $\begin{array}{l}\text { From BIM to } \\
\text { Excel sheet }\end{array}$ & - \\
\hline Shafiq et al. 2015 & $\begin{array}{l}\text { Autodesk Revit } \\
\text { Architecture }\end{array}$ & - & $\begin{array}{l}\text { From BIM to } \\
\text { Excel sheet }\end{array}$ & - \\
\hline Shin et al., 2015 & ArchiCAD 15 & EcoDesigner & $\begin{array}{l}\text { From BIM to } \\
\text { Excel sheet }\end{array}$ & - \\
\hline
\end{tabular}

\subsection{Output data and communication of results}

Communication of results and its usefulness to reduce environmental impacts of buildings and energy consummation of buildings are crucial in the LCA application. Takano et al. [76] underlined the importance of the results communication, as a way to "stimulate environmental consciousness in society". According to EN 15978 [4] the communication of results includes the information about the environmental performance of the building and its characteristics. The assessment results have to be expressed according to a list of environmental impact indicators described in the EN 15978, which can be partially included [4]. 
Regarding reviewed papers, the most calculated environmental impact indicator was $\mathrm{CO} 2$ emissions. More than half of the cases [64-67] were focused on $\mathrm{CO} 2$ emissions during product and operational phase, while Shafiq et al. [70] focused on embodied emissions. Peng [64] and Shin \& Cho [68] developed a Life Cycle $\mathrm{CO} 2$ emissions calculation, comparing emissions from construction, operational and demolition stages. 
Table 4.

Results communication

\begin{tabular}{|c|c|c|c|c|}
\hline Reference & $\begin{array}{l}\text { Environmental } \\
\text { Impact indicators }\end{array}$ & $\begin{array}{l}\text { Sensitivity } \\
\text { analysis }\end{array}$ & $\begin{array}{l}\text { Embodied } \\
\text { CO2 Emissions/yr. } \\
\text { kg/m2/year }\end{array}$ & $\begin{array}{l}\text { Operational } \\
\text { CO2 } \\
\text { Emissions/yr. }\end{array}$ \\
\hline Ajayi et al., 2015 & GWP, HH & - & - & - \\
\hline Basbagill et al., 2013 & EIF & $\mathrm{X}$ & - & - \\
\hline Georges et al. 2014 & ECOE, OCOE & - & $\begin{array}{l}\text { Residential } 7.2 \\
\text { Office } 8.3\end{array}$ & $\begin{array}{l}\text { Residential } 5.1 \\
\text { Office } 4.4\end{array}$ \\
\hline Houlihan et al. 2014 & ECOE, OCOE & - & 7.2 & 5.1 \\
\hline Iddon \& Firth, 2013 & ECOE, OCOE & - & $\begin{array}{l}\text { Scenario1 } 4.9 \\
\text { Scenario } 25.2 \\
\text { Scenario } 35.6 \\
\text { Scenario } 45.0\end{array}$ & $\begin{array}{llll}\text { Scenario } & 1 & 17 \\
\text { Scenario } & 2 & 18 \\
\text { Scenario } & 3 & 21 \\
\text { Scenario } & 4 & 16\end{array}$ \\
\hline Jalaei \& Jrade, 2014 & $\begin{array}{l}\text { AP; EP; GWP; HH; } \\
\text { ODP; PEC; PCSP; } \\
\text { REP; WRRU }\end{array}$ & - & - & - \\
\hline Jrade \& Jalaei, 2013 & $\begin{array}{l}\text { AP; EP; GWP; HH; } \\
\text { ODP; PEC; PCSP; } \\
\text { REP; WRRU }\end{array}$ & - & - & - \\
\hline Lee et al., 2015 & $\begin{array}{l}\text { ADP; AP; EP; GWP; } \\
\text { ODP; POCP }\end{array}$ & - & - & - \\
\hline Peng, 2014 & $\mathrm{COE}$ & $\mathrm{X}$ & $321 *$ & 86.8 \\
\hline Shafiq et al. 2015 & ECOE & - & - & - \\
\hline Shin et al., 2015 & $\mathrm{COE}$ & - & $\begin{array}{l}\text { Original } 132.3^{*} \\
\text { Alternative } 1118.4 \\
* \\
\text { Alternative } 2 \\
132.95^{*}\end{array}$ & $\begin{array}{l}\text { Original } 94 \\
\text { Alternative } 195.07 \\
\text { Alternative } 292.84\end{array}$ \\
\hline
\end{tabular}

Abbreviations: ADP, Abiotic Depletion Potential; AP, Acidification Potential; COE, CO2 Emissions; ECOE, Embodied CO2 Emissions; EFP, Effects Potential; EIF, Embodied Impact Factor; EP, Eutrophication Potential; GWP, Global Warming Potential; HH, Human Health; OCOE, Embodied CO2 Emissions; ODP, Ozone Depletion Potential; P SP, Photo- chemical Smog Potential; PEC, Primary Energy Consumption; POCP, Photochemical Ozone Creation Potential; REP, Respiratory Effects Potential; WRRU, Weighted Raw Resource Use.

* Emissions during construction stage

Iddon \& Firth, 2013, considered a single-family house as the case study. It compared the followings cases: Scenario 1, Tradional Masonry; Scenario 2, Heavyweight; Scenario 3, Timber; Scenario 4, Structural Insulated Panels. Shin et al., 2015 considered three alternatives for the external skin system, including the original external skin system. The study cases included are: Original external skin; Alternative 1: cement brick wall with double-glazed windows; Alternative 2: $24 \mathrm{~mm}$ low-E glass curtain wall. 
Basbagill et al. [49] calculated an Embodied Impact Factor based on the quantity of CO2e (kg) per kilo of materials. In contrast, Jalaei \& Jrade [57] and Jrade \& Jalaei, [58] included the ten most relevant environmental impact indicators categorized by the U.S. Environmental Protection Agency. Lee et al. [59] developed a Parametric Building Element Library, using a library writing method. A shared parameter input method, similar to the BIM data input method [59], was used to match the information necessary for LCA with the library content.

Sensitivity analysis was developed in Basbagill et al. [49] and Peng [64]. The first case [49] was performed to search the minimum and maximum possible embodied impacts due to each building component using a pre-defined range of building shapes and design parameters, and the second case [64] was developed to identify the parameters that have the greatest impact on the building's performance. The study also concluded that, over the 2 years of construction process, 50 years of operational stage, and 0.5 years of demolition, approximately $85.4 \%$ of the total $\mathrm{CO} 2$ emissions were produced during the operation stage, $12.6 \%$ were produced during the construction stage, and $2 \%$ were produced during the demolition stage.

Based on the heterogeneity in the definition of goals and scopes, especially in the lifespan definition, the comparability of results could not be assumed. Therefore, a ratio per year was calculated to compare the cases that have calculated embodied or operational CO2 emissions, as shown in Table 4. Although similar typology cases were assessed, dissimilarities in embodied and operational emissions were detected. For example, the ratio obtained for single-family houses in Iddon et al. [65] was greater for Operational than for Embodied CO2, in contrast to Georges et al. [66] and Houlihan et al. [67], whose ratio was greater for Embodied than Operational CO2.

\section{DISCUSSION AND METHODOLOGICAL CHALLENGE}

\subsection{BIM model LOD and LCA input data}

According to reviewed papers, the level of development (LOD) and the modeling of objects can be considered a key point during the application of LCA. This paper confirmed that the LOD of the model and the BIM software capability to model and automatically quantify several building components, materials and objects, can limit or condition the input data. Houlihan et al.[67], for instance, had to calculate inner and outer wood wall components manually. 
With regard to the model and graphic information, the present review evidence that most of the case studies have not declared the LOD of BIM models used for the LCA, except in two cases - LOD 200 and 300-. The application of LCA during the early stages of design should be done in a LOD that allows a quick modelling, and an easy and reliable environmental impacts checking.

Analyzing the definition of the LCA stages, all the case studies have developed "screening" LCA type studies according to the classification defined by EeBGuide [54]. This is due to the fact that the assessment was mostly focused on the product and the operational energy use, and also considered very few indicators of environmental impacts (mainly $\mathrm{CO} 2$ emissions).

Results show that most of the case studies utilized BIM models during LCI. The most important progress of the BIM-LCA integration with reference to input data, is that the bill of materials quantities can be easily obtained from BIM software tools.

\subsection{Modeling of temporal aspects and information management}

Several cases recognize methodological limitations of the BIM-LCA integration to include scenario verification of different materials and stages temporally separated. Peng [64] recognized that the developed BIM-based LCA method is limited by time and the assumption of production and demolition of materials. The study underlines that these assumptions are based on information related to studies, building contractors, and site measurements. This fact gives evidence of the difficulty of including several life cycle stages into BIM-based LCA. Thus, most of the study cases have focused the LCA application on the LCA stages that can be easily modeled. Therefore, the stages that involve temporal aspects such as replacements, maintenance, refurbishment, repair, deconstruction, disposal and waste treatment were scarcely included. Recycling and reuse potential were not included in any cases.

Moreover, Basbagill et al. [49] provide evidence of the need to include "what if" scenarios for the evaluation of alternative design options.

\subsection{Material properties and data exchange}

According to the analysis of case studies the data contained in BIM databases are not enough to develop the LCA application. This fact is also confirmed by Peng [64]. The authors conclude that BIM cannot provide sufficient data in the early design phase to be used in the LCA, so BIM and LCAs remain vastly 
different [64]. Thus, the analysis of case studies enables confirmation that the bill of material quantities, as well as material properties obtained in the BIM software, was edited manually by the end users in most of the cases studies.

Results evidence that to improve the data exchange between BIM and LCA, BIM models should include more information about material properties and constructive characteristics of buildings, adapting BIM model databases to the LCA method data structure. This means, for example, that BIM software can help to segregate materials of each component and also can help in the quantification of constructive aspects such as welding, and thermal insulating products for thermal bridges. Ajayi et al. [33], for instance, used a Microsoft Excel spreadsheet to manually segregate each of the building components.

Moreover, several material properties had to be based on other sources (apart from BIM databases) to obtain the environmental impacts of materials. Lee [59], for example, obtained the quantities of building materials by the Revit BIM authoring, and the estimation of embodied environmental impact was developed by a unit conversion factor. It was developed analyzing the specific material (size and density information), based on the Korean Industrial Standard certification specification. In addition, Peng [64], for example, highlighted that in several cases data about materials or components properties have to be added to BIM databases by the end user in advance.

\subsection{Interoperability and data exchange}

Interoperability in BIM is a key aspect; it allows various stakeholders to work together and software to exchange information [77]. BIM tools developed by individual software companies have been criticized for addressing interoperability among their own products [78]. This makes it more difficult to spread the use of BIM, especially for various smaller construction companies [56]. Most of the case studies have used Autodesk Revit to develop the BIM model, one of the most widely-used BIM software. This fact gives evidence of the need to develop new tools based on open BIM schemas and especially in IFC data models.

In contrast, the limitation of several Energy Consumption calculation software linked to BIM software to achieve energy codes and regulations has already been underlined by several studies. Peng [79] highlighted that Ecotect cannot be used to meet codes or regulations which also suffers from long run times.

According to the reviewed papers, the detected methods for BIM-LCA in terms of data and software exchange are the following: the development of a template including environmental data about building 
materials [59], the development of a plug-in added to the BIM software and linked to LCA software [57], the integration of environmental data in Energy Demand calculation software linked to BIM [64], the combination of different tools using BIM tools for the quantification of building materials, environmental databases, and LCA tools (from basic to complete) $[33,49,58,65-68,70]$. This review shows that the LCA calculation has been developed in half of the case studies by complete LCA tools. Several cases have developed a basic LCA application, based on the quantification of $\mathrm{CO} 2$ emissions.

\subsection{Usefulness of results}

The reviewed papers demonstrate that the integration of BIM-LCA can simplify and help to obtain quick and effective results during the early stages of design, in spite of the fact that their comparability can hardly be assured. In contrast, the use of results as aided design techniques was verified in Basbagill et al. [49] and Peng [64]. They integrate sensitive analysis; a technique that can help to obtain a range of parameters around a nominal value [46]; it also represents a useful tool during the early stages of design. According to Saltelli [80] the sensitive analysis "is the study of how the uncertainty in the output of a model can be apportioned to different sources of uncertainty in the model input".

\section{CONCLUSIONS}

This review provides evidence of the growing interest in the integration of BIM with environmental impact calculation methods. However, literature about the subject is still scarce. The paper shows that the integration of BIM-LCA has mainly been developed in new buildings or projects, confirmed in $90 \%$ of case studies; its utility from early stages of design has been mostly recognized. However, its use in existing buildings was also verified. Furthermore, this paper confirms that almost half of the case studies developed an environmental impact assessment based on LCA but focused on energy life cycle.

The paper also demonstrates that there is still some way to go before the automatic exchange between BIM and LCA application during the early stages of design. This paper also evidences certain limitations in BIM software for the building modeling of several building elements and materials and temporal processes such as use, refurbishments, maintenance, repair and end of life stages, as well as the recycling and reuse potential.

There is also detected that the integration of BIM-LCA can be developed in three levels. The first one integrates the BIM as a tool, during the LCI stage for the quantification of materials and building elements. 
The second level, in addition to using BIM as a tool to quantify and organize building materials and components, integrates environmental information to BIM software or to Energy Building Evaluation. The third level involves the development of automated process combining different data and software.

Moreover, several limitations are recognized in detected BIM-based LCA methods. The use of green templates, based on the link of BIM and sustainable material databases, is limited to embodied impacts, recommended for preliminary stages of design. The case studied that developed plug-ins for specific BIM software linked to LCA software has the advantage of immediate results, and the disadvantages of limited BIM software authoring implementation and the application to few life cycle stages. It may be used during the design process, especially for a preliminary selection of materials. The integration of environmental data in Energy Demand Calculation Software linked to BIM cases is recommended for use in those which calculate few environmental indicators (e.g. CO2 emissions) and apply a partial LCA (e.g. construction, maintenance and demolition). The combination of different tools using BIM models for the quantification of building materials, environmental databases, and LCA tools (from basic to complete), has the advantage of including more environmental impact categories and the disadvantage of the requirement of more manually edited data. Therefore, it is recommended for a complete LCA application during early stages of design, allowing the end user to select material characteristics, transport distances, and construction techniques, etc.

Related to the BIM model LOD, the paper evidences that the integration of BIM-LCA seems to be appropriate in models which have defined the most relevant materials and components, including: wall thickness (including component layers), and the definition of structural elements in their actual engineered sizes, shapes, and locations. According to this, the LOD 300 seems to be the most appropriate to verify the environmental impacts during the early stages of design.

The paper also confirms that the integration of BIM-LCA allows at least a "screening" LCA application that can be mainly used during early stages, and also allows the feedback of both tools. It is also confirmed that the integration of BIM-LCA can reduce the efforts in data input and can also be applied as a useful tool to compare building materials and energy scenarios, although several limitations were also detected. 
This paper also highlights several recommendations and challenges for end users and software developers for the improvement of the tool integration.

For end users, the integration of BIM-LCA should help designers and engineers to obtain quick and reliable results about the environmental performance of buildings, since the early stages of design. Thus, one of the most important challenges for them is to know and understand the processes involved during the life cycle of the building. In order to achieve the full potential of that, end users should have more control over processes and characteristics of building materials during the life cycle, such as transport distances, lifespan of materials and construction processes.

For software developers, one of the greatest challenges is to improve the interoperability between both tools. Thus, it should be closer to the development of tools that can be compatible with open file format specification such as IFC data format rather than to the development of plug-ins for specific BIM software. This is because the first solution allows a more complete assessment during the building life cycle and also facilitates the scope of the application of the LCA method into the AEC sector.

Another significant challenge is to improve the data exchange between BIM and LCA, in order to automatize the application in the AEC sector. The complexity of associating each material and building component with the unit processes during the life cycle of the building (e.g. transport, maintenance, envelope) is detected as a major difficulty. Therefore, to automatize data exchange, it is necessary to adapt material properties and the bill of material quantities from BIM software to LCA method data structure. Moreover, data source interoperability should ensure the local representation of data and the building characteristics, without demanding so much effort of end users.

Finally, this paper evidences that BIM-based LCA must go further than the calculation of several environmental impacts (such as embodied energy or $\mathrm{CO} 2$ emissions of materials) in few life cycle stages. It should provide the end user with an environmental impact assessment of the building as close as possible to the particular characteristics of the building, its context, and over its complete life cycle.

This paper evidences the need to assist in the integration of BIM-LCA, and also underlines the need of future developments with the aim of improve and standardize its integration. It also evidences further 
research focusing on the use of user-friendly platforms that can offer better guarantees to obtain quick, representative and comparable results.

\section{REFERENCES}

[1] M. Yeheyis, K. Hewage, M.S. Alam, C. Eskicioglu, R. Sadiq, An overview of construction and demolition waste management in Canada: a lifecycle analysis approach to sustainability, Clean Technol. Environ. Policy. (2012) 81-91. doi:10.1007/s10098-012-0481-6.

[2] European Commission, Servide Contract on management of construction and demolition waste SR1, 2011. http://ec.europa.eu/environment/waste/pdf/2011_CDW_Report.pdf.

[3] European Commission, EUROSTAT, 2010. http://ec.europa.eu/atwork/synthesis/aar/aar2010/doc/estat_aar_2010.pdf.

[4] EN 15978, BS EN 15978:2011 - Sustainability of construction works - Assessment of environmental performance of buildings - Calculation method, Int. Stand. (2011).

[5] EN 15643-1, EN 15643-1:2010 - Sustainability of construction works -Sustainability assessment of buildings - Part 1 : General framework, Int. Stand. (2010) 1-25.

[6] EN 15643-3, EN 15643-3:2012 - Sustainability of construction works - Assessment of buildings Part 3 : Framework for the assessment of social performance, Int. Stand. (2012) 1-36.

[7] EN 15643-4, EN 15643-4:2012 - Sustainability of construction works - Assessment of buildings Part 4 : Framework for the assessment of economic performance, Int. Stand. (2012) 1-36. doi:EN 15643-4.

[8] H.J. Kang, Development of a systematic model for an assessment tool for sustainable buildings based on a structural framework, Energy Build. 104 (2015) 287-301. doi:10.1016/j.enbuild.2015.07.015.

[9] S. Azhar, W.A. Carlton, D. Olsen, I. Ahmad, Building information modeling for sustainable design and LEED $®$ rating analysis, Autom. Constr. 20 (2011) 217-224. doi:10.1016/j.autcon.2010.09.019.

[10] Z. Alwan, P. Jones, P. Holgate, Strategic sustainable development in the UK construction industry, through the framework for strategic sustainable development, using Building Information Modelling, J. Clean. Prod. (2016). doi:10.1016/j.jclepro.2015.12.085.

[11] O. Ortiz, F. Castells, G. Sonnemann, Sustainability in the construction industry: A review of 
recent developments based on LCA, Constr. Build. Mater. 23 (2009) 28-39. doi:10.1016/j.conbuildmat.2007.11.012.

[12] F. Asdrubali, C. Baldassarri, V. Fthenakis, Life cycle analysis in the construction sector: Guiding the optimization of conventional Italian buildings, Energy Build. 64 (2013) 73-89. doi:10.1016/j.enbuild.2013.04.018.

[13] B. Soust-Verdaguer, C. Llatas, A. García-Martínez, Simplification in life cycle assessment of single-family houses: a review of recent developments, Build. Environ. 103 (2016) 215-227. doi:10.1016/j.buildenv.2016.04.014.

[14] D. Kellenberger, H.J. Althaus, Relevance of simplifications in LCA of building components, Build. Environ. 44 (2009) 818-825. doi:10.1016/j.buildenv.2008.06.002.

[15] S. Lasvaux, N. Schiopu, J. Chevalier, B. Peuportier, Relevance of a French simplified life cycle inventory database using building products industry data, in: Int. Symp. Life Cycle Assess. Constr., Nantes, France, 2012: pp. 46-54.

[16] T. Malmqvist, M. Glaumann, S. Scarpellini, I. Zabalza, A. Aranda, E. Llera, S. D??az, Life cycle assessment in buildings: The ENSLIC simplified method and guidelines, Energy. 36 (2011) 1900-1907. doi:10.1016/j.energy.2010.03.026.

[17] S. Kota, J.S. Haberl, M.J. Clayton, W. Yan, Building Information Modeling (BIM)-based daylighting simulation and analysis, Energy Build. 81 (2014) 391-403. doi:10.1016/j.enbuild.2014.06.043.

[18] K. Barlish, K. Sullivan, How to measure the benefits of BIM - A case study approach, Autom. Constr. 24 (2012) 149-159. doi:10.1016/j.autcon.2012.02.008.

[19] D. Bryde, M. Broquetas, J.M. Volm, The project benefits of building information modelling (BIM), Int. J. Proj. Manag. 31 (2013) 971-980. doi:10.1016/j.ijproman.2012.12.001.

[20] N.W. Young Jr., S. Jones, H. Bernstein, The business value of BIM: Getting building information modeling to the bottom line, 2009.

[21] J.K.W. Wong, J. Zhou, Enhancing environmental sustainability over building life cycles through green BIM: A review, Autom. Constr. 57 (2015) 156-165. doi:10.1016/j.autcon.2015.06.003.

[22] L. Antón Álvarez, J. Díaz, Integration of life cycle assessment in a BIM environment, Procedia Eng. 85 (2014) 26-32. doi:10.1016/j.proeng.2014.10.525.

[23] H. Kreiner, A. Passer, H. Wallbaum, A new systemic approach to improve the sustainability 
performance of office buildings in the early design stage, Energy Build. 109 (2015) 385-396. doi:10.1016/j.enbuild.2015.09.040.

[24] KT Innovations, Autodesk, Tally-Autodesk, (2014). http://choosetally.com/.

[25] Official Journal of the European Union, DIRECTIVE 2014/24/EU, 2014. http://eurlex.europa.eu/legal-content/EN/TXT/PDF/?uri=CELEX:32014L0024\&from=es.

[26] HM Government, Construction 2025, 2015.

[27] R. Volk, J. Stengel, F. Schultmann, Building Information Modeling (BIM) for existing buildings Literature review and future needs, Autom. Constr. 38 (2014) 109-127. doi:10.1016/j.autcon.2013.10.023.

[28] A.I. of A. AIA, Guide, Instructions and Commentary to the 2013 AIA Digital Practice Documents, 2013.

[29] M. Medas, D. Cheshire, A. Cripps, J. Connaughton, M. Peters, Towards BIM-integrated, resource-efficient building services, in: CIBSE Tech. Symp., 2015: pp. 1-8.

[30] L.Á. Antón, J. Díaz, Integration of LCA and BIM for Sustainable Construction, World Acad. Sci. Eng. Technol. Int. J. Soc. Educ. Econ. Manag. Eng. 8 (2014) 1356-1360.

[31] A. Hope, Z. Alwan, Building the Future: Integrating Building Information Modelling and Enviornmental Assessment Methodologies, in: First UK Acad. Conf. BIM, 2012: pp. 87-95. http://nrl.northumbria.ac.uk/8098/.

[32] B. Hardin, D. McCool, BIM and Construction Management, Indianapolis, USA, 2009.

[33] S.O. Ajayi, L.O. Oyedele, B. Ceranic, M. Gallanagh, K.O. Kadiri, Life cycle environmental performance of material specification: a BIM-enhanced comparative assessment, Int. J. Sustain. Build. Technol. Urban Dev. 6 (2015) 14-24. doi:10.1080/2093761X.2015.1006708.

[34] A. Akbarnezhad, K.C.G. Ong, L.R. Chandra, Z. Lin, Economic and Environmental Assessment of Deconstruction Strategies Using Building Information Modeling, Constr. Res. Congr. (2012) 1730-1739. doi:10.1061/9780784412329.174.

[35] U.A. Umar, N. Shafiq, M. Amirhossein, M.F. Nuruddin, A.F. Syed, I.U. Salihi, Application of Structural Building Information Modeling (S-BIM) for Sustainable Buildings Design and Waste Reduction: A Review, Int. J. Appl. Eng. Res. Volume 11 (2016) 1523-1532. http://www.ripublication.com/ijaer16/ijaerv11n2_132.pdf.

[36] E. Kriegel, B. Nies, Green BIM: Successful Sustainable Design with Building Information 
Modeling, Wiley Publishing, Indianapolis, USA, 2008.

[37] M. Rahmani Asl, S. Zarrinmehr, M. Bergin, W. Yan, BPOpt: A framework for BIM-based performance optimization, Energy Build. 108 (2015) 401-412. doi:10.1016/j.enbuild.2015.09.011.

[38] D. Mah, J.D. Manrique, H. Yu, M. Al-Hussein, R. Nasseri, House construction CO $<\mathrm{DN}>2</ \mathrm{DN}>$ footprint quantification: a BIM approach, Constr. Innov. Information, Process. Manag. 11 (2011) 161-178. doi:10.1108/14714171111124149.

[39] P. Rajendran, C. Pathrose, Implementing BIM for waste minimisation in the construction industry, in: Proc. 2nd Int. Conf. Manag., 2012: pp. 557-570. http://www.internationalconference.com.my/proceeding/icm2012_proceeding/043_191_2ndICM 2012_Proceeding_PG0557_0570.pdf.

[40] Z. Liu, M. Osmani, P. Demian, A. Baldwin, A BIM-aided construction waste minimisation framework, Autom. Constr. 59 (2015) 1-23. doi:10.1016/j.autcon.2015.07.020.

[41] A. Ahankoob, S.M. Khoshnava, R. Rostami, C. Preece, A. Technology, Bim perspectives on construction waste reduction, Manag. Constr. Res. Assoc. (2012) 195-199.

[42] F.K.T. Cheung, J. Rihan, J. Tah, D. Duce, E. Kurul, Early stage multi-level cost estimation for schematic BIM models, Autom. Constr. 27 (2012) 67-77. doi:10.1016/j.autcon.2012.05.008.

[43] M. Buyle, J. Braet, A. Audenaert, Life cycle assessment in the construction sector: A review, Renew. Sustain. Energy Rev. 26 (2013) 379-388. doi:10.1016/j.rser.2013.05.001.

[44] ISO, ISO 14040: Environmental management — Life Cycle Assessment — Principles and Framework, Environ. Manage. 3 (2006) 28. doi:10.1002/jtr.

[45] L.F. Cabeza, L. Rincón, V. Vilariño, G. Pérez, A. Castell, Life cycle assessment (LCA) and life cycle energy analysis (LCEA) of buildings and the building sector: A review, Renew. Sustain. Energy Rev. 29 (2014) 394-416. doi:10.1016/j.rser.2013.08.037.

[46] M. Lotteau, P. Loubet, M. Pousse, E. Dufrasnes, G. Sonnemann, Critical review of life cycle assessment (LCA) for the built environment at the neighborhood scale, Build. Environ. 93 (2015) 165-178. doi:10.1016/j.buildenv.2015.06.029.

[47] A. Sharma, A. Saxena, M. Sethi, V. Shree, Varun, Life cycle assessment of buildings: A review, Renew. Sustain. Energy Rev. 15 (2011) 871-875. doi:10.1016/j.rser.2010.09.008.

[48] V. Motuzienè, A. Rogoža, V. Lapinskienè, T. Vilutienė, V. Motuziene, A. Rogoža, V. 
Lapinskiene, T. Vilutiene, Construction solutions for energy efficient single-family house based on its life cycle multi-criteria analysis: a case study, J. Clean. Prod. 112 (2016) 532-541. doi:10.1016/j.jclepro.2015.08.103.

[49] J. Basbagill, F. Flager, M. Lepech, M. Fischer, Application of life-cycle assessment to early stage building design for reduced embodied environmental impacts, Build. Environ. 60 (2013) 81-92. doi:10.1016/j.buildenv.2012.11.009.

[50] I. Zabalza Bribián, A. Aranda Usón, S. Scarpellini, Life cycle assessment in buildings: State-ofthe-art and simplified LCA methodology as a complement for building certification, Build. Environ. 44 (2009) 2510-2520. doi:10.1016/j.buildenv.2009.05.001.

[51] S. Roh, S. Tae, S. Shin, Development of building materials embodied greenhouse gases assessment criteria and system (BEGAS) in the newly revised Korea Green Building Certification System (G-SEED), Renew. Sustain. Energy Rev. 35 (2014) 410-421. doi:10.1016/j.rser.2014.04.034.

[52] M. Weissenberger, W. Jensch, W. Lang, The convergence of life cycle assessment and nearly zero-energy buildings: The case of Germany, Energy Build. 76 (2014) 551-557. doi:10.1016/j.enbuild.2014.03.028.

[53] H. Gervasio, P. Santos, R. Martins, L. Simoes da Silva, A macro-component approach for the assessment of building sustainability in early stages of design, Build. Environ. 73 (2014) 256270. doi:10.1016/j.buildenv.2013.12.015.

[54] EeB Guide Project, Operational Guidance for Life Cycle Assessment Studies of the Energy Efficient Buildings Initiative, (2012). http://www.eebguide.eu/.

[55] KTH and all partners contributions, ENSLIC Project. Guidelines for LCA calculations, (2010) 52. https://ec.europa.eu/energy/intelligent/projects/en/projects/enslic-building.

[56] J. Gantner, S. Schneider, M. Fischer, A. Lozanovski, F. Gehring, BIM as a data source for LCA and building certification schemes Certification schemes and BIM as a possible solution German research project BIMiD, in: New Zel. LIfe Cycle Assess. Conf., 2014: pp. 116-119.

[57] F. Jalaei, A. Jrade, An Automated BIM Model to Conceptually Design, Analyze, Simulate, and Assess Sustainable Building Projects, Hindawi. 2014 (2014) 1-21. doi:10.1155/2014/672896.

[58] A. Jrade, F. Jalaei, Integrating building information modelling with sustainability to design building projects at the conceptual stage, Build. Simul. 6 (2013) 429-444. doi:10.1007/s12273- 
013-0120-0.

[59] S. Lee, S. Tae, S. Roh, T. Kim, Green Template for Life Cycle Assessment of Buildings Based on Building Information Modeling: Focus on Embodied Environmental Impact, Sustainability. 7 (2015) 16498-16512. doi:doi:10.3390/su71215830.

[60] T. Håkkinen, A. Kiviniemi, Sustainable Building and BIM, in: World Conf. SB08, 2008: pp. $679-686$.

[61] S. Seo, S. Tucker, P. Newton, Automated material selection and environmental assessment in the context of 3D building modelling, J. Green Build. 2 (2007) 51-61.

[62] T. Rist, A path to BIM-based LCA for whole-buildings, 2011. http://www.ntnu.edu/documents/139834/7683624/p072.pdf.

[63] E. Loh, N. Dawood, J. Dean, Integration of 3D tool with Environmental Impact Assessment (3D EIA), in: 3rd Inter- Natl. ASCAAD Conf. Embodying Virtual Archit., Alexandria, Egypt, 2007.

[64] C. Peng, Calculation of a building's life cycle carbon emissions based on Ecotect and building information modeling, J. Clean. Prod. 112 (2014) 453-465. doi:10.1016/j.jclepro.2015.08.078.

[65] C.R. Iddon, S.K. Firth, Embodied and operational energy for new-build housing: A case study of construction methods in the UK, Energy Build. 67 (2013) 479-488. doi:10.1016/j.enbuild.2013.08.041.

[66] L. Georges, M. Haase, A. Houlihan Wiberg, T. Kristjansdottir, B. Risholt, Life cycle emissions analysis of two nZEB concepts, Build. Res. Inf. 43 (2014) 82-93. doi:10.1080/09613218.2015.955755.

[67] A. Houlihan Wiberg, L. Georges, T.H. Dokka, M. Haase, B. Time, A.G. Lien, S. Melleg??rd, M. Maltha, A net zero emission concept analysis of a single-family house, Energy Build. 74 (2014) 101-110. doi:10.1016/j.enbuild.2014.01.037.

[68] Y. Shin, K. Cho, BIM Application to Select Appropriate Design Alternative with Consideration of LCA and LCCA, Math. Probl. Eng. Hindawi Publ. Corp. (2015) 14 pages. doi:dx.doi.org/10.1155/2015/281640.

[69] Norwegian standard, NS 3451:2009 - Table of building elements, 2009.

[70] N. Shafiq, M.F. Nurrudin, Fadhil, S.S.S. Gardezia, A. Bin Kamaruzzaman, Carbon footprint assessment of a typical low rise office building in Malaysia using building information modelling (BIM), Int. J. Sustain. Build. Technol. Urban Dev. 6 (2015) 157-172. 
doi:10.1080/2093761X.2015.1057876.

[71] Athena Sustainable Materials Institute, Athena Impact Estimator, 2016. (n.d.). http://www.athenasmi.org/.

[72] G. Hammond, C. Jones, Embodied Carbon The Inventory of Carbon and Energy, BSRIA BG 10/2011, (2011). http://urn.kb.se/resolve?urn=urn:nbn:no:ntnu:diva-13635.

[73] Korea Life Cycle Inventory, (2015). http://www.edp.or.kr/lci/lci.asp.

[74] K. (Eds. . The National Greenhouse Gas Inventories Programme, Eggleston, H.S., Buendia, L., Miwa, K., Ngara, T., Tanabe, 2006 IPCC Guidelines for National Greenhouse Gas Inventories, IGES, Japan, 2006.

[75] DECC, The Government's Standard Assessment Procedure for Energy Rating of Dwellings 2009 version 9.9, 2011.

[76] A. Takano, A. Hafner, L. Linkosalmi, S. Ott, M. Hughes, S. Winter, Life cycle assessment of wood construction according to the normative standards, Eur. J. Wood Wood Prod. 73 (2015) 299-312. doi:10.1007/s00107-015-0890-4.

[77] F.K.T. Cheung, J. Rihan, J. Tah, D. Duce, E. Kurul, Early stage multi-level cost estimation for schematic BIM models, Autom. Constr. 27 (2012) 67-77. doi:10.1016/j.autcon.2012.05.008.

[78] R. Jardim-Goncalves, A. Grilo, Building information modeling and interoperability, Autom. Constr. 19 (2010) 387. doi:10.1016/j.autcon.2009.11.008.

[79] C. Peng, W. Xiao, Case Study of Carbon Emissions from a Building's Life Cycle Based on BIM and Ecotect, Hindawi. (2015) 15. doi:dx.doi.org/10.1155/2015/954651.

[80] A. Saltelli, Sensitivity analysis for importance assessment, in: Risk Anal., 2002: pp. 579-590. doi:10.1111/0272-4332.00040. 